Rethinking Relationship Marketing as Consumer Led and Technology

Driven: Propositions for Research and Practice

Rooney, Tara $a$

Krolikowska, Ewa $b^{*}$

Bruce, Helen L. $c$

a College of Business, School of Marketing, Technological University Dublin, Dublin, Ireland.

b Faculty of Business, University of Greenwich, London, U.K. ke22@gre.ac.uk

c Lancaster University Management School, Lancaster University, Lancaster, U.K.

*Corresponding author 


\title{
Rethinking Relationship Marketing as Consumer Led and Technology Driven: Propositions for Research and Practice
}

\begin{abstract}
The study of Relationship Marketing (RM) has led to improved understanding and management of customer relationships. However, it has suffered recent criticism for firm-centricity, and for failing to address the impact of the technological revolution and resulting customer empowerment in firm-customer relationships. This paper addresses these limitations by reconceptualizing RM as consumer led, with firm interactions enabling consumers to create their own unique experiences and value through the increasing accessibility of innovative technologies. This, in turn, benefits the firm through reciprocated value and beneficial relationship outcomes. We critically review extant knowledge and derive five propositions about firm-customer relationships. These propositions form the basis of managerial implications and a research agenda to better understand the impact of technologies and customer experience on RM.
\end{abstract}

Keywords: relationship marketing; technology; customer experience; customer relationship; consumer relationship

\section{Introduction}

The emergence of relationship marketing (RM) as a field of study has led to an improved understanding and management of customer relationships (Zhang, Watson, Palmatier, \& Dant, 2016), a shift from transactional marketing to an era of relationships (Coviello, Brodie, \& Munro, 1997), and permanent changes for marketing practice (Palmatier, Dant, Grewal, \& Evans, 2006). RM is now an established field of research, focusing on the generation of knowledge relating to the initiation, maintenance and enhancement of 
mutually beneficial relationships between customers and firms (Gummerus, von Koskull, \& Kowalkowski, 2017).

Recent commentary, however, has challenged the extent to which RM research continues to drive truly impactful advances in knowledge. O'Malley (2014) asserts that RM research perpetuates a management-orientation, which views customers as passive recipients rather than active agents in interactions and subsequent value creation. In this scenario, value is predefined by the firm and transferred to the customer at the point of delivery (Zeithaml, 1988). This is in contrast with contemporary perspectives such as the customer-dominant logic, which conceptualizes value as arising from consumers' embedding products, services and experiences within their daily lives (Heinonen and Strandvik, 2015). Within the RM literature, the value for the firm in building relationships with customers is clearly documented. For instance, Palmatier et al.'s (2006) metaanalytic framework of RM antecedents and mediators highlights outcomes of effective RM, such as customer loyalty and positive word of mouth communication. What is less evident within the RM literature, is where the value of relationships with firms lies for consumers. Tobaccowala and Jones (2018) suggest that customers are not interested in building relationships, but are only concerned with brands providing them with the products, services and experiences they need to achieve their goals. This perspective presents relationship marketing theory with a perplexing problem: how can it remain relevant in a marketplace where consumers seek greater autonomy?

Moreover, Payne and Frow (2017) observe that much RM research overlooks recent developments in technology and its impact on customers' relationships with firms. Specifically, the ubiquity of smart connected devices alters both the context and dynamics of customer relationships with firms (Payne and Frow, 2017). Simultaneously, analysts predict that by 2020 , there will be around 20.8 billion globally connected devices (Servion 
Global Solutions, 2018) with individuals managing $85 \%$ of their relationships with firms without any human interaction (Gartner, 2011). Porter and Heppelmann (2015) add that smart, connected products mean engagement with customers involves a continuous open dialogue. They suggest that such devices are the conduit to delivering value because devices are connected, so relationships with customers are always ongoing. Additionally, the nature of interactions will move from traditional textual and/or visual communications to voice activated communications, facilitated through mediated devices (Jones, 2018). This shift from how relationships have been traditionally built inevitably requires firms to access more emotional, sensorial and social responses from customers.

Similarly, Hong and Wang (2009) argue that our understanding of the interplay between RM constructs such as trust and commitment requires reassessment. They add that as these technologies become ubiquitous, connected and seamless, they allow customers to build relationships with firms in the absence of a lengthy time period. Furthermore, social media technologies present fresh and dynamic ways for firms to connect with customers by improving interactions and building stronger relationships (Kim \& Ko, 2012). However conversely, they inherently facilitate fact track style relationships which may be weaker in bond ties (Donath \& Boyd, 2004) and subsequently easier to terminate. These trends have the potential to empower and embolden consumers, such that they take an increasingly active role in value creation (Balaji \& Roy, 2017).

The exponential growth in technology presents marketers with abundant new opportunities to connect with consumers. However, it also creates abundant challenges around cultivating relationships as it further weakens the extent to which consumers can be thought of as 'passive' recipients of RM activities (O'Malley, 2014). It is therefore not surprising that a joint practitioner-academic consultation has identified "examining how the Internet of Things and smart services can enhance the customer experience and 
influence relationships between customers and service providers" as a key area of focus (Ostom, Parasuraman, Bowen, Patricio, \& Voss, 2015, p. 143). However, current RM theory has adopted a fragmented rather than holistic approach to understanding the role of technology in building customer relationships (Steinhoff, Arli, Weaven, \& Kozlenkova, 2019). Consequentially, in order for RM to remain relevant in this dramatically changing landscape, more research is required which takes a customer led perspective on relationships. In addition, we need to acknowledge that technology is no longer the facilitator of firm to customer relationships but has become a primary relationship driver.

Therefore, the aim of this paper is to conceptualize the extent to which RM can be repurposed as customer led, in order to strengthen its theoretical and practical position in a technology-centric landscape where consumers are empowered. This is needed to address the dominant firm-orientation within prior works (e.g. Palmatier et al., 2006). Correspondingly, it must also reflect the technological context within which marketplace relationships now exist. We achieve our aim in three main ways. First, we draw upon the customer experience construct and associated theory to reconceptualize RM by positioning the firm's actions within the consumer's world. Second, we integrate extant knowledge regarding the impact of technology on consumers' experiences and subsequent relationships. Third, we present five key propositions derived from our review with corresponding supporting tenets from the extant literature. Fourth, we propose a new definition of RM based on our reconceptualization and expand our propositions into a renewed RM research agenda and managerial implications. 


\section{A customer experience view of relationship marketing}

The benefits of building long-term customer relationships over discrete exchanges have been well documented since the 1980s (Berry, 1983; Dwyer, Schurr, \& Oh, 1987). In the 1990s, researchers were hailing RM as a new paradigm shift (Grönroos, 1994; Coviello et al., 1997) and focusing on effective management of customer trust and commitment (Morgan \& Hunt, 1994) and retaining customers through loyalty programmes (Hart, Smith, Sparks, and Tsokas, 1999). It was assumed that the firm was the active party driving the relationship and the customer was the passive recipient. However, in the late 1990s, the Experience Economy emerged based on offering customers desirable experiences as a way of building advantage through involving them in creating their own value (Pine \& Gilmore, 1998). Recent literature has moved away from the functionality of building strong relationships to staging customer experiences (CE) which can have a transformative effect on customers (Kim, Beckman, \& Agogino, 2018). Firms have recognized the importance of CE by employing dedicated CE managers and focusing on the large variety of touchpoints that comprise a customer's journey with a firm (Lemon and Verhoef, 2016). Trivedi (2019) observes that businesses now offer customers experiences to build strong relationships. Keiningham et al. (2017) argue that CE drives customers' commitment to firms and is also influenced by customers' evolving commitment throughout multiple or continued interactions.

Scholars define CE in multi-dimensional terms as encompassing customers' cognitive, emotional, behavioral, sensorial and social responses to their interactions with firms, products or brands (Lemon \& Verhoef, 2016). Interactions and associated responses accumulate over time, and include direct contacts with a firm, its representatives or its offering, and indirect interactions outside the control of the firm, such as discussing a firm with another customer, or reading a product review (Verhoef et al. 2009). The multiple 
interactions comprising CE encompass many of the antecedents of effective RM, identified in prior studies as tools available to firms (Palmatier et al., 2006), such as marketing communications (Rosengren \& Dahlén, 2015) and loyalty schemes (MeyerWaarden, 2008). Other empirically established antecedents and mediators of effective RM activity by firms constitute customers' responses to their interactions with the firm, be they cognitive, emotional, social or behavioral. For instance, Chai and Dibb (2014) highlight the impact of consumers developing cognitive and affective trust in their relationships with financial service providers. Moreover, positive CE and successful RM activity are understood to drive common benefits for the firm, such as loyalty, satisfaction, retention and positive word of mouth communication (Maklan \& Klaus, 2011; Lemke, Clark, \& Wilson, 2011).

Logically, then, applying a CE lens to the concept of a relationship between a consumer and a firm addresses the firm-centricity inherent in much RM research (O’Malley, 2014). It positions the relationship as a connection between the consumer and the firm that is perceived by the consumer rather than assumed by the firm. It results from the consumer's direct and indirect interactions with the firm and their subsequent multidimensional responses. We therefore offer our first proposition:

P1: Consumers' perceived relationships with firms consist of enduring or repeated interactions with a firm, its representatives or its offering, which may be driven by the consumer in pursuit of valued cognitive, emotional, behavioral, social or sensorial responses. 
Table 1 P1 Reconceptualizing Relationship Marketing as Customer Led

\begin{tabular}{|c|c|c|}
\hline $\begin{array}{l}\text { Propositions supporting the } \\
\text { reconceptualization of RM } \\
\text { as Customer Led }\end{array}$ & Supporting tenets & Supporting literature \\
\hline \multirow{3}{*}{$\begin{array}{l}\text { Proposition 1 } \\
\text { Consumers' perceived } \\
\text { relationships with firms } \\
\text { consist of enduring or } \\
\text { repeated interactions with a } \\
\text { firm, its representatives or its } \\
\text { offering, which may be driven } \\
\text { by the consumer in pursuit of } \\
\text { valued cognitive, emotional, } \\
\text { behavioral, social or sensorial } \\
\text { responses. }\end{array}$} & $\begin{array}{l}\text { Creating superior } \\
\text { experiences is a way of } \\
\text { encouraging customers to } \\
\text { interact with firms and build } \\
\text { a relationship. }\end{array}$ & $\begin{array}{l}\text { Verhoef et al. } 2009 \\
\text { Scholz and Duffy, } 2018 \\
\text { Scholz and Smith, } 2016\end{array}$ \\
\hline & $\begin{array}{l}\text { CE-enabled direct and } \\
\text { indirect interactions between } \\
\text { customers and firms builds } \\
\text { more enduring consumer } \\
\text { relationships. }\end{array}$ & $\begin{array}{l}\text { Verhoef et al. } 2009 \\
\text { Steinhoff et al. } 2019 \\
\text { Trivedi, } 2019\end{array}$ \\
\hline & $\begin{array}{l}\text { Consumers are willing to } \\
\text { make the effort to engage } \\
\text { with firms if these } \\
\text { interactions lead to perceived } \\
\text { benefits, which also creates } \\
\text { beneficial outcomes for the } \\
\text { firm such as satisfaction and } \\
\text { loyalty. }\end{array}$ & $\begin{array}{l}\text { Helkkula et al. } 2012 \\
\text { Maklan and Klaus, } 2011 \\
\text { Lemke et al. } 2011\end{array}$ \\
\hline
\end{tabular}

Value is considered to be a central concept in the study and practice of relationship marketing (Payne \& Holt, 2001). Earlier studies tend to focus on value to the firm (Payne \& Holt, 2001; Grönroos, 2000), Customer value was assumed to be predetermined by the firm, deriving from the firm's offering and activities (Helkkula, Kelleher, \& Pihilström, 2012). As early as the late 1990s, the importance of identifying customer-driven customer value, by examining how customers use products in their own world, had been recognised (Woodruff, 1997). However, this was before the technologies were available to capture this data in real time. Customer value was initially based on economic value and utility of the product (Zeithaml, 1988). However as the interest in customer perceived value grew, it was conceptualized as a multidimensional and phenomenological concept which transcends economic value and includes emotional, sensorial and experiential elements (Helkkula et al. 2012; Tynan, McKechnie, \& Hartley, 2014; Weidmann, Labenz, Haase, \& Hennigs, 2017). 
Customer experience provides a rich context for the multi-dimensional elements of value to be realized. Value in the experience has been conceptualized as both personal and social (Helkkula et al. 2012). While value can be uniquely subjective, it can also take the form of social capital which can be shared with others in a customer's network. This relational dimension of social capital resides in relationship marketing concepts such as trust and trustworthiness (Naphiet \& Ghoshal, 1998). Thus, social capital can be considered a value driver in consumer-firm relationships. The concept of value networks reflects that value is no longer contained within the firm-customer dyad but created and distributed within a wider ecosystem of firms, customers and other stakeholders (Helkkula et al. 2012) made more accessible through technology. Indeed, a complicating factor arises in an increasingly technological environment where, for example, social networking sites enable users to maintain weak relational ties quite easily, quickly and at little to no cost (Neves \& Fonseca, 2015, Donath \& Boyd 2004). This subsequently presents new challenges for establishing long term meaningful relationships with customers.

Within the value network, firms engage in targeted interactions with consumers, for example, through social media and relational communications. This contributes to the consumer's overall experience and can lead to trusting relationships and customer loyalty for the organization (Ahuja \& Alavi, 2018). The extent to which such interactions are viewed as representative of a relationship depends upon the consumers' responses to both these and prior interactions. Consumers might, for instance, welcome firm-initiated contact and perceive it as cementing their relationship. Alternatively, such attempts at interaction might be ignored by consumers, perhaps because they feel no connection to the firm or have not experienced value in the relationship. Indeed, relationship value has mainly been studied as a phenomenon occurring in a business to business context 
(Skarmeas, Zeriti, \& Baltas, 2016; Ehret, 2004), perhaps implying that consumers do not seek value in relationships with firms. In order for consumers to perceive the relationship to exist, firms need to consider how to design interactions which enable customers to attain the most meaningful types of value for themselves. Consequently, we offer our second proposition:

P2: Firm interactions need to be designed to help consumers create their own value through experiences and this builds the consumers' perceived relationship with the firm.

Table 2 P2 Reconceptualizing Relationship Marketing as Customer Led

\begin{tabular}{|c|c|c|}
\hline $\begin{array}{l}\text { Propositions supporting the } \\
\text { reconceptualization of RM } \\
\text { as Customer Led }\end{array}$ & Supporting tenets & Supporting literature \\
\hline \multirow{3}{*}{$\begin{array}{l}\text { Proposition } 2 \\
\text { Firm interactions need to be } \\
\text { designed to help consumers } \\
\text { create their own value } \\
\text { through experiences and this } \\
\text { builds the consumers' } \\
\text { perceived relationship with } \\
\text { the firm. }\end{array}$} & $\begin{array}{l}\text { Firms can use multisensory } \\
\text { marketing to create unique } \\
\text { experiences which provide } \\
\text { customer perceived value } \\
\text { and brand strength. }\end{array}$ & $\begin{array}{l}\text { Wiedmann et al. } 2018 \\
\text { Tynan et al. } 2014 \\
\text { Petit et al. } 2019\end{array}$ \\
\hline & $\begin{array}{l}\text { When firms give tools to } \\
\text { customers to create their } \\
\text { own value, customers will } \\
\text { reciprocate by giving value } \\
\text { to the firm, thus creating a } \\
\text { relationship based on mutual } \\
\text { benefit. }\end{array}$ & $\begin{array}{l}\text { Ahuja and Alavi, } 2018 \\
\text { Itani et al. } 2019 \\
\text { Scholz and Duffy, } 2018\end{array}$ \\
\hline & $\begin{array}{l}\text { Customer-firm interactions } \\
\text { take place within wider } \\
\text { value networks which means } \\
\text { that value from the } \\
\text { experience is not only dyadic } \\
\text { (between customer and firm) } \\
\text { but can be shared across the } \\
\text { network. }\end{array}$ & $\begin{array}{l}\text { Helkkula et al. } 2012 \\
\text { Steinhoff et al. } 2019 \\
\text { Ehret, } 2004\end{array}$ \\
\hline
\end{tabular}

In the next section, we examine the different ways in which technology is impacting relationship marketing and put forward three further propositions for consideration. 


\section{Transforming relationship marketing in the technology-infused ecosystem}

The increasing accessibility of technology is dramatically changing how consumers and firms interact in an integrated (physical, digital and social) service ecosystem (Bolton et al., 2018). Relatedly, research has tentatively explored the role of online relationship marketing (ORM) activities and how they might facilitate relationship marketing objectives (Boateng, 2019). However, despite the resultant advances in knowledge, focussing solely on ORM is in itself limiting. The pace of innovation has accelerated such that a seamless and connected ecosystem of distinct yet complementary technologies has emerged, through which customers can transform their experiences and control their relationships (Bolton et al., 2018).

Reflecting developments in technology, prior empirical works have explored the impact of novel technologies on the CE. For example, Tung and Au (2018) and Kuo Chen, \& Tseng (2017) study tourists' responses to their interaction with robots deployed in hotels while van Esch et al., (2019) and Balaji and Roy (2017) investigate the impact of augmented reality and the Internet of Things (IoT) on CE. Digital sensory marketing tools such as haptic devices can lead to affective reactions online and increased closeness between consumers and brands (Petit, Velasco, \& Spence, 2019). This arguably enhances a firm's ability to appeal to customers' senses by stimulating them at points along their journey. Empirical studies of the impact of novel technologies on consumer-firm relationships are few, though nascent findings suggest potentially meaningful influences of technology on consumers' perceptions of their relationships with firms (e.g. Camarero, Garrido, \& San Jose, 2018).

Current knowledge is, however, limited by the focus within these studies on a single technology, rather than the ecosystem of integrated technologies available to consumers and marketers (Steinhoff et al., 2019). Marketers can capitalize on these technological 
developments to add value to interactions, increase profitability and improve services (Wang, Head, \& Archer, 2000). Itani, Kassar, and Correia Loureiro (2019) argue that as customer are social beings, they seek to effect social influence through the communities and networks in which they operate. Technology and digital ecosystems amplify a consumer's ability to exert and maximise this social influence. Itani et al. (2019) further add that these networked relational interactions which present in the form of referrals and knowledge sharing, ultimately create value for both the customer and the firm. However, arguably, it is no longer sufficient to simply exploit technology to add value to the relationship (Kim et al., 2018). We contend that firms need to utilize technologies which are now integrated and infused (van Doorn et al., 2017), to transform consumers' interactions by enabling active participation in the experience creation process, thus deriving our third proposition:

P3: The evolving technology ecosystem can assist in transforming consumers' experiences, thus facilitating their autonomous creation of value from their interactions and building stronger relationships between consumers and firms.

Table 3 P3 Reconceptualizing Relationship Marketing as Technology Driven

\begin{tabular}{|l|l|l|}
\hline $\begin{array}{l}\text { Propositions supporting the } \\
\text { reconceptualization of RM } \\
\text { as Technology Driven }\end{array}$ & Supporting tenets & Supporting literature \\
\hline $\begin{array}{l}\text { Proposition 3 } \\
\text { The evolving technology } \\
\text { ecosystem can assist in } \\
\text { transforming consumers } \\
\text { experiences, thus facilitating } \\
\text { their autonomous creation of } \\
\text { value from their interactions } \\
\begin{array}{l}\text { and building stronger } \\
\text { relationships between } \\
\text { consumers and firms. }\end{array}\end{array}$ & $\begin{array}{l}\text { A more integrated } \\
\text { technological environment } \\
\text { changes how consumers are } \\
\text { interacting with firms in the } \\
\text { service ecosystem and how } \\
\text { firms can achieve relational } \\
\text { objectives. }\end{array}$ & $\begin{array}{l}\text { Bolton et al., 2018 } \\
\text { Boateng, 2019 }\end{array}$ \\
\cline { 2 - 3 } $\begin{array}{l}\text { Relationships are now built } \\
\text { within the digital ecosystem } \\
\text { whereby emergent integrated } \\
\text { and connected technologies } \\
\text { can transform customer } \\
\text { experiences, }\end{array}$ & Bolton et al 2019 \\
Camarero et al., 2018 \\
\end{tabular}




\begin{tabular}{|l|l|l|}
\hline & $\begin{array}{l}\text { Developments in the digital } \\
\text { ecosystem allows firms to } \\
\text { add value to customer } \\
\text { interactions and thus, } \\
\text { improve relationships. }\end{array}$ & $\begin{array}{l}\text { Wang et al., 2000 } \\
\text { Kim et al., 2018, }\end{array}$ \\
\hline
\end{tabular}

As firms integrate novel technologies within their operations, the role of the firm within relationships evolves as elements of relationship development and management are increasingly delegated to technology-based applications (Lo \& Campos, 2018). Traditional CRM systems that deploy intelligent technologies to guide firms around how best to develop and strengthen relationships with customers (Sheth, 2017), are being superseded by tools that autonomously determine and orchestrate those techniques. In this context, consumers will be building relationships with devices and objects that have "agency, autonomy, and authority" and therefore possess "their own unique capacities for interaction" (Novak \& Hoffman, 2019, p 216). While customers will be actively engaged in this process in both the real and virtual worlds, they will also be passively engaged through connected objects in their homes and workplaces. These devices have the ability to communicate amongst themselves and are therefore capable of better satisfying customer goals and needs (Verhoef et al., 2017). Subsequently, the connectivity and access provided by the IoT has the potential to reshape industry boundaries, even create new industries and business models, and redefine the traditional service provider-client relationship (Leminen, Rajahonka, Westerlund, \& Wendelin, 2018). Conversely, it also has the power to strengthen relationships customers have with the technology itself (Jones, 2018) rather than brands using the technology. Ultimately, technology has now evolved to a level whereby the technology rather than firm representatives, is building connections and co-creating value with customers (Verhoef et al., 2017) thus enhancing the customer experience (Bolton et al., 2018). 
Prior studies have established that consumers can form positive and meaningful relationships with inanimate objects (Belk 1988; Novak \& Hoffman, 2019). However, recent research highlights that consumers are now building relationships with mediated and smart devices; statistics show that half a million customers have gone so far as to declare their love to Amazon's Alexa (GeekWire, 2015). Consequently, branded technologies can now arbitrate consumers' relationships with firms which infers that the strength of firm-customer relationships will be influenced by the relationship a customer has with a branded technology. Furthermore, automation technologies such chatbots and robotics also facilitate the building of human to non-human relationships (Chung, Ko, Joung, \& Kim, 2018). Social networking sites incorporate AR and VR technologies, enhancing consumer-firm relationships through interactions with the firm and with other remote customers. This increases the potential for indirect interactions within the customer experience and further empowers the consumer in their relationships with firms. While the development of non-human to human relationships is largely under-researched, it represents an evolution in the nature of relationships between consumers and firms that looks set to continue as, for instance, socially intelligent robotics (robots which appear to have social qualities and display signs of empathy) emerge (Bolton et al., 2018). Consequently, we offer our fourth proposition:

P4: Consumers' may form relationships with technology-based non-human firm representatives and intermediaries, rather than with firms themselves, meaning that the value a customer derives from a relationship will be contingent on their relationship with the relevant branded technology, reducing the control and influence firms have on relationship building activities. 
Table 4 P4 Reconceptualizing Relationship Marketing as Technology Driven

\begin{tabular}{|c|c|c|}
\hline $\begin{array}{l}\text { Propositions supporting the } \\
\text { reconceptualization of RM } \\
\text { Technology Driven }\end{array}$ & Supporting tenets & Supporting literature \\
\hline \multirow{4}{*}{$\begin{array}{l}\text { Proposition } 4 \\
\text { Consumers' may form } \\
\text { relationships with technology- } \\
\text { based non-human firm } \\
\text { representatives and } \\
\text { intermediaries, rather than } \\
\text { with firms themselves, } \\
\text { meaning that the value a } \\
\text { customer derives from a } \\
\text { relationship will be } \\
\text { contingent on their } \\
\text { relationship with the relevant } \\
\text { branded technology, reducing } \\
\text { the control and influence } \\
\text { firms have on relationship } \\
\text { building activities. }\end{array}$} & $\begin{array}{l}\text { New integrated technologies } \\
\text { require a reassessment of the } \\
\text { role of the firm within } \\
\text { consumer relationships with } \\
\text { aspects of the relationship } \\
\text { becoming allocated to } \\
\text { technology-based } \\
\text { applications }\end{array}$ & Lo and Campos, 2018 \\
\hline & $\begin{array}{l}\text { Relationships will be built } \\
\text { between consumers and } \\
\text { devices that are increasingly } \\
\text { self-sufficient, have agency } \\
\text { and consequently, influence. }\end{array}$ & $\begin{array}{l}\text { Novak and Hoffman, 2019, } \\
\text { Verhoef et al., } 2017\end{array}$ \\
\hline & $\begin{array}{l}\text { Customers will use mediated } \\
\text { and connected integrated } \\
\text { technology to better direct } \\
\text { and satisfy their relationships } \\
\text { with firms which can } \\
\text { redefine the terms of } \\
\text { consumer relationships }\end{array}$ & $\begin{array}{l}\text { Verhoef et al., 2017, } \\
\text { Leminen et al., } 2018\end{array}$ \\
\hline & $\begin{array}{l}\text { Relationship maintenance } \\
\text { and growth will operate } \\
\text { between human and non- } \\
\text { human relationships }\end{array}$ & $\begin{array}{l}\text { Chung et al., } 2018 \\
\text { Bolton et al., } 2018\end{array}$ \\
\hline
\end{tabular}

In order to build meaningful and strong relationships with customers, firms must participate effectively within a technologically-infused ecosystem to facilitate positive customer experiences (Trivedi, 2019). The success of this agenda, however, depends on a firm's ability to better understand how smart and connected technologies impact the development and maintenance of consumer relationships. In particular, firms need to understand the role trust and commitment play in this dynamic (Boateng \& Narteh, 2016). Recent discourse has focussed on the importance of trust in the digital environment acknowledging it as essential to relationship building (Briggs \& Douglas, 2010; Brun, Rajaobelina, \& Ricard, 2014). However, our understanding of how concepts like trust 
operate in digital environments is poor, with little research considering the role of trust in a technologically-infused ecosystem.

The emergence of trust as a central concept for building relationships in an digital environment is not surprising given the remote nature of digital exchanges (Zhou, 2011a; Rice, 2012). More recently, trust has become increasingly important in the context of consumer privacy. As technology has become better at collecting customer data, to be stored, analyzed and disseminated as a means of influence purchasing behavior, customers become more suspicious of how their data is being used. Where trust is perceived as being undermined, trust friction can become problematic in digital environments. Friction arises in the presence of poorly managed infrastructures, inferior functionality, weak regulatory/legal requirements and poor data security, resulting in high levels of uncertainty (Chakravorti, Bhalla, \& Chaturvedi, 2018). Consequentially, most current research focuses on institutional trust mechanisms to build trusting digital environments by providing structural assurances, enhancing perceptions of quality, security, privacy, ease of use and reputation (Zhou, 2011b). Other trust concepts such as levels of perceived risk are also central to managing customers' concerns when engaging with technology, particularly smart technologies such as chatbots (Trivedi, 2019). The relationship between trust and perceived risk is positive in that increasing the former reduces the latter. However, prior research does not consider the role of trust relationship formation from a technology-infused perspective, preferring to examine trust in a specific technology context such as digital trust or AI trust. Consequentially, our current understanding of trust in an infused and connected ecosystem is fragmented and insufficient.

Moreover, the array of technologies available provides platforms for firms to act opportunistically. De Cremer, Nguyen, and Simkin (2016) argue that IoT practices can 
"manifest behavior that damages or even destroys interfirm and customer relationships" (p 146). Furthermore, they suggest malicious and exploitative IoT practices relating to the collection of consumer data, the purposeful development of complex ecosystems to trap customers, confusing and difficult to understand contracts, contractual obligations embedded in 'fine print' and so on, can damage customer relationships. They call for more research into the dark-side behaviors of firms in IoT environments. While the 'techlash' effect still impacts how consumers view technology, research has shown that regardless of technology scandals such as Facebook and Cambridge Analytica, in 2019 trust in technology modestly increased while conversely trust in business sectors, educators and CEOs decreased (Edelman, 2019). To complicate the issue, the privacy paradox also suggests that while consumers grow increasingly concerned about privacy, they remain very willing to disclose vast amounts of personal information online. This leads us to our fifth and final proposition:

P5: As smart and connected devices in both real and virtual worlds collect, analyze and disseminate consumer data at an unprecedented level, relationship constructs such as trust, commitment and perceived risk will become imperative to successful experience facilitation and enhanced consumer relationships.

Table 5 P5 Reconceptualizing Relationship Marketing as Technology Driven

\begin{tabular}{|c|c|c|}
\hline $\begin{array}{l}\text { Propositions supporting the } \\
\text { reconceptualization of RM } \\
\text { Technology Driven }\end{array}$ & Supporting tenets & Supporting literature \\
\hline \multirow{2}{*}{$\begin{array}{l}\text { Proposition } \mathbf{5} \\
\text { As smart and connected } \\
\text { devices in both real and } \\
\text { virtual worlds collect, analyze } \\
\text { and disseminate consumer } \\
\text { data at an unprecedented } \\
\text { level, relationship constructs } \\
\text { such as trust, commitment and } \\
\text { perceived risk will become } \\
\text { imperative to successful }\end{array}$} & $\begin{array}{l}\text { Trust in the digital } \\
\text { ecosystem is a central } \\
\text { concept in understanding } \\
\text { how to effectively build and } \\
\text { maintain consumer } \\
\text { relationships within the } \\
\text { digital ecosystem. }\end{array}$ & $\begin{array}{l}\text { Boateng and Narteh, 2016, } \\
\text { Briggs and Douglas, 2010; } \\
\text { Brun et al., 2014, } \\
\text { Zhou, 2011a } \\
\text { Rice, 2012 }\end{array}$ \\
\hline & $\begin{array}{l}\text { Mediated technologies will } \\
\text { provide the potential for trust } \\
\text { friction to emerge as }\end{array}$ & $\begin{array}{l}\text { Chakravorti et al., } 2018 \\
\text { De Cremer et al., (2016) }\end{array}$ \\
\hline
\end{tabular}




\begin{tabular}{|l|l|l|}
\hline $\begin{array}{l}\text { experience facilitation and } \\
\text { enhanced consumer } \\
\text { relationships. }\end{array}$ & $\begin{array}{l}\text { consumers become } \\
\text { suspicious of how their data } \\
\text { and behaviour is being } \\
\text { monitored, controlled and } \\
\text { stored. }\end{array}$ & \\
\cline { 2 - 3 } & $\begin{array}{l}\text { The role of institutional trust } \\
\text { will continue to develop in } \\
\text { digital ecosystems but will } \\
\text { require integration with trust } \\
\text { theory and concepts to gain a } \\
\text { complete understanding of } \\
\text { how trust is fostered in } \\
\text { digital environments. }\end{array}$ & Zhou, 2011b \\
Trivedi, 2019 & \\
\hline
\end{tabular}

\section{Implications for Practice and Future Research}

In this section, we set out the implications of the five propositions from our earlier discussions for firms involved in RM practices. This is followed by a research agenda (see Table 6) to advance the future generation of impactful knowledge by scholars regarding the theory and practice of RM. Firm-oriented definitions of relationships stress their mutual benefits to customers and firms (Gummerus et al., 2017). However, relationship marketers need to acknowledge the consumer's pursuit of personal benefit through experience as central to a successful relationship building strategy. Therefore, we propose that a definition of RM is required which is customer-led and conceptualized from a CE/technology lens: $R M$ is a means of initiating, accumulating and, where necessary, discontinuing direct and indirect interactions between parties embedded in complex, dynamic and technologically-infused ecosystems, where those interactions evoke valued experiences.

Firms need to be aware of the diversity of interaction and subsequent response which, for the consumer, will dictate whether a relationship exists as well as whether it is perceived as positive. This involves recognizing meaningful responses from consumers who are actively engaged e.g. adding content to a brand's feed on Instagram, rather than treating all responses as important e.g. a 'like' on Facebook. However, some of these 
responses may be complex and difficult to capture, for example, Keiningham et al. (2017) argue that customer commitment cannot be measured objectively since it is influenced by the customer's perception of their experience as well as the type of commitment which the brand is trying to develop (affective, economic etc.). RM studies have often used customer retention or relationship continuity intention (Palmatier et al., 2006) as relationship outcomes, which do not necessarily represent the consumer's acknowledgement that the relationship exists. Consequently, we argue that firms need to monitor relationship measures which reflect consumer advocacy such word of mouth (Sundermann, 2018) and customer citizenship behavior (Curth, Uhrich, \& Benkenstein, 2014). These measures also take into account that consumers are influenced by and influence other consumers. Subsequently firm-led interactions should include encouraging $\mathrm{C} 2 \mathrm{C}$ exchanges to reach their target audiences.

Technology plays a key role in driving customer interactions and enabling their experiences, and its impact is set to grow. This is starkly evident in, for instance, the automotive industry where cars are being developed to respond to drivers 'moods' by adjusting settings which alter the lighting, music and temperature within the car through accessing real time sensory data. Technology is also vital in monitoring consumer responses in real time so the firm can respond quickly, thus increasing engagement and promoting positive interactions. Responses can be captured using AI, customer-facing camera technology, VR technology, software that analyzes facial expressions and rapidly developing mood detection systems. Customer responses should be gathered longitudinally and combined with relational measures such as share of wallet and more sensorial measures such as emotional responses, to get a holistic view of the relationship through the customer's experience. 
We also argue that firms need to invest in learning about how consumers integrate multiple platforms and how they create personal value through their interactions with technology. For example, mobile shopping apps can provide an opportunity for fun and play, deepening the consumer's sense of self which impacts positively on the relationship with the brand (Scholz \& Duffy, 2018) by building social capital in the customer's personal network (Tynan et al., 2014). Furthermore, as consumers move between human and non-human interactions, firms need to understand the infrastructure required so that this is a seamless transition, avoiding disruption to the customer experience. They must consider the impact of the diversity of interactions on brand consistency and the impact of technology failure or shortcomings on the consumer's relationship with the brand (Scholz \& Duffy, 2018). Through the technology ecosystem, the brand has the potential to become more meaningful as a relationship partner to the consumer through its association with their unique experience.

However, firms need to acknowledge that the consumer may believe their relationship to be with the branded technology (the AR shopping app or the intelligent personal assistant) and not the firm itself. This adds a new layer to RM theory that has not yet been considered: the role branded mediated technologies play in firm-customer relationship development. In effect, there may be a positive or negative halo effect from the customer's relationship with the branded technology device to the firm-customer relationship, which is being facilitated through the device. Such branded devices therefore add a new dynamic to relationship formation and maintenance. Furthermore, such technologies increase customer control and empower their choices while the firm can use the data collected through these intermediaries to better understand the consumer experience and form more meaningful relationships. In this environment, B2B 
relationships operating at the back end of the mediated technology will be foundational in developing $\mathrm{B} 2 \mathrm{C}$ relationships.

Finally, firms need to understand how consumers perceive risk and how their concerns around issues such as privacy and data security impact their experience. In this uncertain and complex world, RM constructs such as trust and commitment will give relationships an added value. However, there is currently little knowledge available on how these constructs operate in this technology-infused ecosystem. Nevertheless, firms need to make sure that they do not act opportunistically in managing consumers' data as unethical use of IoT practices can damage or even terminate the customer-firm relationship (De Cremer et al., 2016).

Emerging from the previous discussions, we offer the following research questions aligned with our propositions, to help researchers advance impactful knowledge to progress the theory and practice of RM.

Table 6. Research Agenda

\begin{tabular}{|l|l|}
\hline Proposition & Research Questions \\
\hline $\begin{array}{l}\text { P1: Consumers' perceived } \\
\text { relationships with firms consist of } \\
\text { enduring or repeated interactions } \\
\text { with a firm, its representatives or its } \\
\text { offering, which may be driven by } \\
\text { the consumer in pursuit of valued } \\
\text { cognitive, emotional, behavioral, } \\
\text { social or sensorial responses. }\end{array}$ & $\begin{array}{l}\text { - } \\
\text { When does a CE become a perceived relationship: } \\
\text { is there a critical number, type or intensity of } \\
\text { response that results in the consumer perceiving a } \\
\text { connection with a firm? }\end{array}$ \\
\hline $\begin{array}{l}\text { P2: Firm interactions need to be } \\
\text { designed to help consumers create } \\
\text { fheir own value through experiences } \\
\text { encourages them to disconnect? }\end{array}$ & $\begin{array}{l}\text { Are CE and RM complementary constructs } \\
\text { facilitated by technology? }\end{array}$ \\
perceived relationship with the firm. & $\begin{array}{l}\text { Do consumers attach different levels of } \\
\text { importance to firm-led vs consumer-led or C2C } \\
\text { interactions: which leads to the most valued } \\
\text { responses driving the stronger relationships? }\end{array}$ \\
& $\begin{array}{l}\text { Which tools/interactions are most effective in } \\
\text { value creation in different contexts e.g. retail vs } \\
\text { healthcare, where consumers have varying levels } \\
\text { of autonomy? }\end{array}$ \\
\hline
\end{tabular}




\begin{tabular}{|c|c|}
\hline & $\begin{array}{l}\text { How does the social sharing of value consumers } \\
\text { create from firm interactions lead to a stronger } \\
\text { perceived relationship with the firm? }\end{array}$ \\
\hline $\begin{array}{l}\text { P3: The evolving technology } \\
\text { ecosystem can assist in transforming } \\
\text { consumers' experiences, thus } \\
\text { facilitating consumers' their } \\
\text { autonomous creation of value from } \\
\text { their interactions and building } \\
\text { stronger relationships between } \\
\text { consumers and firms. }\end{array}$ & $\begin{array}{l}\text { What role does technology play in value } \\
\text { cocreation? } \\
\text { What value do customers seek when engaging } \\
\text { with firms though technology - sensorial, } \\
\text { utilitarian, economic etc? } \\
\text { How does a technology-infused ecosystem } \\
\text { enhance/undermine firm-customer relationships? }\end{array}$ \\
\hline $\begin{array}{l}\text { P4: Consumers may form } \\
\text { relationships with technology-based } \\
\text { non-human firm representatives and } \\
\text { intermediaries, rather than with } \\
\text { firms themselves, meaning that the } \\
\text { value a customer derives from a } \\
\text { relationship will be contingent on } \\
\text { their relationship with the relevant } \\
\text { branded technology, reducing the } \\
\text { control and influence firms have on } \\
\text { relationship building activities. }\end{array}$ & $\begin{array}{l}\text { To what extent are consumers aware of the firm } \\
\text { behind the technology? Could corrupt firms or } \\
\text { those which are negatively perceived use } \\
\text { technology to obscure their identity from } \\
\text { consumers? } \\
\text { How can firms maintain a meaningful presence, } \\
\text { have brand visibility/consistency and cater for } \\
\text { those consumers who still require a human touch? } \\
\text { Does this increase operational costs i.e. managing } \\
\text { a dual business model which has human-human } \\
\text { and human-non-human interactions? } \\
\text { Is there a transference effect present between } \\
\text { branded-mediated devices and firm-customer } \\
\text { relationships? }\end{array}$ \\
\hline $\begin{array}{l}\text { P5: As smart and connected devices } \\
\text { in both real and virtual worlds } \\
\text { collect, analyze and disseminate } \\
\text { consumer data at an unprecedented } \\
\text { level, relationship constructs such as } \\
\text { trust, commitment and perceived } \\
\text { risk will become imperative to } \\
\text { successful experience facilitation } \\
\text { and enhanced consumer } \\
\text { relationships. }\end{array}$ & $\begin{array}{l}\text { - Are consumers aware of what is happening to } \\
\text { their data as they interact online: how does this } \\
\text { impact on their experience and relationship with } \\
\text { the firm? } \\
\text { - What are the impacts of firms' dark-side } \\
\text { behaviors (such as trust breaches) on the } \\
\text { consumer? } \\
\text { - How can trust be redefined and reconceptualized to } \\
\text { reflect the way in which consumers are interacting } \\
\text { and forming relationships in an infused and } \\
\text { connected ecosystem? }\end{array}$ \\
\hline
\end{tabular}

\section{Conclusion}

RM has been criticized by researchers in recent years as being overly firm-focussed and slow to respond to the transformation of firm-consumer relationships through technology-driven customer empowerment. Therefore, it is of utmost importance to consider how RM can remain relevant in a marketplace where consumers seek greater autonomy. To this end, our paper's aim was to reposition RM as customer led and 
technology driven. Based on our analysis of recent literature, we generated five propositions which present possibilities for firms and researchers in leveraging an infused technology environment to enhance experience and build relationships. However, we argue that the tools we currently utilize, both theoretical and practical, are insufficient to tackle the expansiveness and exponential development of technology, which is changing the very fabric of how firms and customers engage. We posit that there is no silver bullet in response to this dilemma. As technology continues to develop at an alarming pace, the way forward is inevitably uncharted. Future success will require a process of strategic trial and error. Developing relationships in this new dynamic landscape requires a reimagining of what we currently know, and bravery to let go of the old and familiar, and embrace new solutions for an experiential and technology driven world. 


\section{References}

Ahuja, V., \& Alavi, S. (2018). Using Facebook as a Digital Tool for Developing Trust amongst Consumers using Netnography and Social Media Analytics: A Study of Jet Airways. Journal of Relationship Marketing, 17(3), 171-187.

Balaji M.S., \& Kumar Roy, S. (2017). Value co-creation with Internet of things technology in the retail industry. Journal of Marketing Management, 33(1-2), 7-31

Belk, R.W. (1988). Possessions and the extended self. Journal of Consumer Research. 15(2), 139-168.

Berry L.L. (1983) 'Relationship Marketing' in Berry, L.L, Shostack, L. and Upah, G. (eds.) Emerging Perspectives on Services Marketing, Chicago, American Marketing Association.

Berry, L.L. (1995). Relationship Marketing of Services - Growing Interest, Emerging Perspectives. Journal of the Academy of Marketing Science, 23(4), 236-245.

Boateng, S.L. (2019). Online relationship marketing and customer loyalty: a signaling theory perspective. International Journal of Bank Marketing, 37(1), 226-240.

Boateng, S.L., \& Narteh, B. (2016). Online relationship marketing and affective customer commitment-The mediating role of trust. Journal of Financial Services Marketing, 21(2), 127-140.

Bolton, R.N., McColl-Kennedy, J.R., Cheung, L., Gallan, A., Orsingher, C., Witell, L., \& Zaki, M. (2018). Customer experience challenges: bringing together digital, physical and social realms. Journal of Service Management, 29(5), 776-808.

Briggs, E., \& Douglas, G. (2010). Service Performance-Loyalty Intentions Link in a Business to-Business Context: The Role of Relational Exchange Outcomes and Customer Characteristics. Journal of Service Research, 13(1), 37-51.

Brun, I., Rajaobelina, L., \& Ricard, L. (2014). Online relationship quality: scale development and initial testing. International Journal of Bank Marketing, 32(1), 5-27.

Camarero, C., Garrido, M. J., \& San Jose, R. (2018). What works in facebook content versus relational communication: a study of their effectiveness in the context of museums. International Journal of Human-Computer Interaction, 34(12), 1119-1134.

Chai, J.C.Y. \& Dibb, S., (2014). How consumer acculturation influences interpersonal trust. Journal of Marketing Management, 30(1-2), 60-89. 
Chakravorti, B., Bhalla, A., \& Chaturvedi, R.S. (2018). The 4 Dimensions of Digital Trust, Charted Across 42 Countries. Harvard Business Review Digital Articles, $2-8$.

Chung, M., Ko, E., Joung, H. \& Kim, S.J. (in press) Chatbot e-service and customer satisfaction regarding luxury brands, Journal of Business Research, (available online 10 November, 2018).

Coviello, N., Brodie, R. \& Munro, H. (1997). Understanding contemporary marketing: development of a classification scheme. Journal of Marketing Management, 13(6), 501-22.

Curth, S., Uhrich, S. \& Benkenstein, M. (2014). How commitment to fellow customers affects the customer-firm relationship and customer citizenship behavior. Journal of Services Marketing, 28(2), 147-158.

De Cremer, D., Nguyen, B., \& Simkin, L. (2017). The integrity challenge of the Internet-of-Things (IoT): on understanding its dark side. Journal of Marketing Management, 33(1-2), 145-158.

Donath, J., \& Boyd, D. (2004). Public displays of connection. bt technology Journal, 22(4), 71-82.

Dwyer, F. R., Schurr, P. H. and Oh, S. (1987), Developing buyer-seller relationships. Journal of Marketing, 51(2), 11-27.

Edelman (2019) Trust Barometer, Retrieved 12th July, 2019 from https://www.edelman.com/trust-barometer.

Ehret, M. (2004) Managing the trade-off between relationships and value networks. Towards a value-based approach of customer relationship management in business-to-business markets. Industrial Marketing Management, 33, 465- 473.

Gartner (2011) Retrieved 10th July, 2019 from https://www.gartner.com/imagesrv/summits/docs/na/customer360/C360_2011_brochure_FINAL.pdf.

Geekwire (2015) Retrieved 10th July, 2019 from https://www.geekwire.com/2015/one-year-after-amazon-introduced-echo-half-amillion-people-have-told-alexa-i-love-you/

Grönroos, C. (1994). From marketing mix to relationship marketing: Towards a paradigm shift in marketing, Management Decision. 32(2), 4-20. 
Grönroos, C. (2000). 'Relationship Marketing: The Nordic School Perspective'. In: J.N. Sheth \& A. Parvatiyar (eds) Handbook of Relationship Marketing, 95-118, Sage, Thousand Oaks, CA.

Gummerus, J. von Koskull, C. and Kowalkowski, C. (2017). Guest editorial: relationship marketing - past, present and future. Journal of Services Marketing,. 31(1), $1-5$.

Hart, S., Smith, A., Sparks, L., and Tsokas, N. (1999). Are Loyalty Schemes a Manifestation of Relationship Marketing? Journal of Marketing Management, 15, 541562.

Heinonen, K., Strandvik, T., Mickelsson, K.-J., Edvardsson, B., Sundström, E. and Andersson, P. (2010). A customer-dominant logic of service. Journal of Service Management, 21(4), 531-548.

Helkkula, A., Kelleher, C., \& Pihilström, M. (2012). Characterizing Value as an Experience: Implications for Service Researchers and Managers. Journal of Service Research, 15(1), 59-75.

Hong, S., \& Wang, Y. J. (2009). When relationship marketing collides with technology. Journal of Relationship Marketing, 8(3), 218-230.

Itani, O.S., Kassar, A.N., \& Correia Loureiro, S.M. (2019) Value get, value give: The relationships among perceived value, relationship quality, customer engagement, and value consciousness, International Journal of Hospitality Management, 80, 78-90.

Jones, V.K. (2018). Voice-activated change: Marketing in the age of artificial intelligence and virtual assistants. Journal of Brand Strategy, 7(3), 233-245.

Keiningham, T., Ball, J., Benoit, S., Bruce, H.L., Buoye, A., Dzenkovska, J., Nasr, L., Ou, Y., and Zaki, M. (2017). The interplay of customer experience and commitment. Journal of Services Marketing, 31(2), 148-160.

Kim, E., Beckman, S.L., \& Agogino, A. (2018). Design Roadmapping in an Uncertain World: Implementing a Customer-Experience-Focused Strategy. California Management Review, 61(1), 43-70.

Kim, A. J., \& Ko, E. (2012). Do social media marketing activities enhance customer equity? An empirical study of luxury fashion brand. Journal of Business Research, 65, 1480- 1486. 
Kuo, C.M., Chen, L.C., \& Tseng, C.Y. (2017). Investigating an innovative service with hospitality robots. International Journal of Contemporary Hospitality Management, 29(5), 1305-1321.

Lemke, F., Clark, M., \& Wilson, H. (2011). Customer experience quality: an exploration in business and consumer contexts using repertory grid technique. Journal of the Academy of Marketing Science, 39(6), 846-869.

Leminen, S., Rajahonka, M., Westerlund, M., \& Wendelin, R. (2018). The future of the Internet of Things: toward heterarchical ecosystems and service business models, Journal of Business \& Industrial Marketing, 33(6), 749-767

Lemon, K.N., \& Verhoef, P.C. (2016). Understanding customer experience throughout the customer journey. Journal of Marketing, 80(6), 69-96.

Lo, F. \& Campos, N. (2018). Blending Internet-of-Things (IoT) solutions into relationship marketing Strategies. Technological Forecasting \& Social Change, 137, 10-18.

Maklan, S., \& Klaus, P. (2011). Customer experience: are we measuring the right things? International Journal of Market Research, 53(6), 771-772.

Meyer-Waarden, L. (2008). The influence of loyalty programme membership on customer purchase behavior. European Journal of Marketing, 42(1/2), 87-114.

Nahapiet, J., \& Ghoshal, S. (1998). Social capital, intellectual capital, and the organizational advantage. Academy of management review, 23(2), 242-266.

Neves, B. and Fonseca, J. (2015). Latent Class Models in action: Bridging social capital \& Internet usage. Social Science Research, 50, 15-30.

Novak, T.P., \& Hoffman, D.L. (2019). Relationship journeys in the internet of things: a new framework for understanding interactions between consumers and smart objects. Journal of the Academy of Marketing Science, 47(2), 216-237.

O’Malley, L. (2014). Relational marketing: development, debates and directions. Journal of Marketing Management, 30(11/12), 1220-1238.

Ostrom, A.L., Parasuraman, A., Bowen, D.E., Patricio, L., \& Voss, C.A. (2015). Service research priorities in a rapidly changing context. Journal of Service Research 18(2), 127-159.

Palmatier, R.W., Dant, R.P., Grewal, D., \& Evans, K.R. (2006). Factors influencing the effectiveness of relationship marketing: A meta-analysis. Journal of Marketing, 70(4), 136-153. 
Payne, A., \& Frow, P. (2017). Relationship marketing: looking backwards towards the future. Journal of Services Marketing, 31(1), 11-15.

Payne, A. \& Holt, S. (2001). Diagnosing Customer Value: Integrating the Value Process and Relationship Marketing. British Journal of Management, 12, 159-182.

Petit, O., Velasco, C., \& Spence, C. (2019). Digital sensory marketing: Integrating new technologies into multisensory online experience. Journal of Interactive Marketing, 45, 42-61.

Pine, B. J., \& Gilmore, J. H. (1998). Welcome to the experience economy. Harvard Business Review, 76, 97-105.

Porter, M.E., \& Heppelmann, J.E. (2015). How smart, connected products are transforming companies. Harvard Business Review, 93(10), 96-114.

Rice, S.C. (2012). Reputation and uncertainty in online markets: an experimental study. Information Systems Research, 23(2), 436-452.

Rosengren, S., \& Dahlén, M. (2015). Exploring Advertising Equity: How a Brand's Past Advertising May Affect Consumer Willingness to Approach Its Future Ads. Journal of Advertising, 44, 1-13.

Scholz, J., \& Duffy, K. (2018). We ARe at home: How augmented reality reshapes mobile marketing and consumer-brand relationships. Journal of Retailing and Consumer Services, 44, 11-23.

Scholz, J. \& Smith, A.N. (2016) Augmented reality: Designing immersive experiences that maximize consumer engagement. Business Horizons, 59(2), 149-161.

Servion Global Solutions (2018). What Makes Emerging Technologies The Future Of Customer Experience? Retrieved 8 July 2019 from https://servion.com/blog/what-emerging-technologies-future-customer-experience/.

Sheth, J. (2017). Revitalizing relationship marketing. Journal of Services Marketing, 31(1), 6-10.

Skarmeas D, Zeriti A, \& Baltas G. (2016). Relationship Value: Drivers and Outcomes in International Marketing Channels. Journal of International Marketing, 24(1): 22-40.

Steinhoff, L., Arli, D., Weaven, S., \& Kozlenkova, I.V. (2019). Online relationship marketing. Journal of the Academy of Marketing Science, 47(3), 369-393.

Sundermann, L.M. (2018). Share experiences: receiving word of mouth and its effect on relationships with donors. Journal of Services Marketing, 32(3), 322-333. 
Tobaccowala, R., \& Jones, V.K. (2018). To Thrive in Today's Marketing Landscape, Embrace Schizophrenia!. Journal of Current Issues \& Research in Advertising, 39(3), 266-271.

Trivedi, J. (2019). Examining the Customer Experience of Using Banking Chatbots and Its Impact on Brand Love: The Moderating Role of Perceived Risk. Journal of Internet Commerce, 18(1), 91-111.

Tung, V.W.S., \& Au, N. (2018). Exploring customer experiences with robotics in hospitality. International Journal of Contemporary Hospitality Management, 30(7), 2680-2697.

Tynan, C., McKechnie, S., \& Hartley, S. (2014). Interpreting value in the customer service experience using customer-dominant logic. Journal of Marketing Management. 30(9-10), 1058-1081.

Van Doorn, J., Mende, M., Noble, S.M., Hulland, J., Ostrom, A. L., Grewal, D., \& Petersen, J.A. (2017). Domo arigato Mr. Roboto: Emergence of automated social presence in organizational frontlines and customers' service experiences. Journal of Service Research, 20(1), 43-58.

van Esch, P., Arli, D., Gheshlaghi, M.H., Andonopoulos, V., von der Heidt, T., \& Northey, G. (2019). Anthropomorphism and augmented reality in the retail environment. Journal of Retailing and Consumer Services, 49, 35-42.

Verhoef, P.C., Lemon, K.N., Parasuraman, A., Roggeveen, A., Tsiros, M., \& Schlesinger, L. A. (2009). Customer experience creation: Determinants, dynamics and management strategies. Journal of Retailing, 85(1), 31-41

Verhoef, P.C., Stephen, A.T., Kannan, P.K., Luo, X., Abhishek, V., Andrews, M., Bart, Y., Datta, H., Fong, N., Hoffman, D.L., Hu, M.M., Novak, T., Rand, W. \& Zhang, Y., (2017). Consumer connectivity in a complex, technology-enabled, and mobile-oriented world with smart products. Journal of Interactive Marketing, 40, 1-8.

Wang, F., Head, M., \& Archer, N. (2000). A relationship-building model for the Web retail marketplace. Internet Research, 10(5), 374-384.

Wiedmann, K.-P., Labenz, F., Haase, J., \& Hennigs, N. (2018). The power of experiential marketing: exploring the causal relationships among multisensory marketing, brand experience, customer perceived value and brand strength. Journal of Brand Management, 25(2), 101-118 . 
Woodruff, Robert B. (1997). Customer Value: The Next Source for Competitive Advantage. Journal of the Academy of Marketing Science, 25(2), 139-153.

Zeithaml, V.A. (1988). Consumer perceptions of price, quality, and value: A means-end model and synthesis of evidence. Journal of Marketing, 52(3), 2-22.

Zhang, J.Z., Watson IV, G.F., Palmatier, R.W. and Dant, R.P. (2016). Dynamic relationship marketing. Journal of Marketing, 80(5), 53-75.

Zhou, T. (2011a). An empirical examination of initial trust in mobile banking. Internet Research, 21(5), 527-540.

Zhou, T. (2011b). The effect of initial trust on user adoption of mobile payment. Information Development, 27(4), 290-300. 